\title{
Corrigendum: implications of the lack of desiccation tolerance in recalcitrant seeds
}

\section{Patricia Berjak* and Norman W. Pammenter}

Plant Germplasm Conservation Research, School of Life Sciences, University of KwaZulu-Natal, Durban, South Africa

*Correspondence: berjak@ukzn.ac.za

Edited by:

Jill Margaret Farrant, University of Cape Town, South Africa

Reviewed by:

John Moore, Stellenbosch University, South Africa

Keywords: cryopreservation, dehydration, desiccation damage, desiccation sensitivity, ice crystallization, recalcitrant

\section{A corrigendum on}

Implications of the lack of desiccation tolerance in recalcitrant seeds

by Berjak, P., and Pammenter, N. W. (2013). Front. Plant Sci. 4:478. doi: 10.3389/fpls.2013.00478

An error appears on p. 3, column 2, 4th line from end. The concentrations of NaDCC should appear as $0.30-0.50 \%$ (and not as $0.03-0.05 \%)$.

Conflict of Interest Statement: The authors declare that the research was conducted in the absence of any commercial or financial relationships that could be construed as a potential conflict of interest.

Received: 02 March 2014; accepted: 13 March 2014; published online: 03 April 2014.

Citation: Berjak P and Pammenter NW (2014)

Corrigendum: implications of the lack of desiccation tolerance in recalcitrant seeds. Front. Plant Sci. 5:123. doi: 10.3389/fpls.2014.00123

This article was submitted to Plant Physiology, a section of the journal Frontiers in Plant Science.

Copyright (c) 2014 Berjak and Pammenter. This is an open-access article distributed under the terms of the Creative Commons Attribution License (CC BY). The use, distribution or reproduction in other forums is permitted, provided the original author(s) or licensor are credited and that the original publication in this journal is cited, in accordance with accepted academic practice. No use, distribution or reproduction is permitted which does not comply with these terms. 